\title{
Impact of Planting Dates and Climatic Factors on the Incidence and Severity of Sorghum Grain Mold in Morelos, Mexico
}

R. Montes-Belmont, Centro de Desarrollo de Productos Bióticos, Instituto Politécnico Nacional, Apartado Postal 24, 62731, Yautepec, Morelos; I. Méndez-Ramírez, Instituto de Investigaciones en Matemáticas Aplicadas y en Sistemas, Universidad Nacional Autónoma de México, Apartado Postal 20-726, 0100 México, D.F.; and H. E. Flores-Moctezuma and R. A. Nava-Juárez, Centro de Desarrollo de Productos Bióticos, Instituto Politécnico Nacional, Apartado Postal 24, 62731, Yautepec, Morelos

\begin{abstract}
Montes-Belmont, R., Méndez-Ramírez, I., Flores-Moctezuma, H. E., and Nava-Juárez, R. A. 2003. Impact of planting dates and climatic factors on the incidence and severity of sorghum grain mold in Morelos, Mexico. Plant Dis. 87:1139-1143.

It is difficult to develop control strategies for grain mold of sorghum because of the limited information on the epidemiology of grain mold in Mexico. The objectives of this study were to identify the fungi associated with grain mold in Morelos, Mexico, and to explore the relationship among planting dates, disease development, and relative humidity and temperature. Fusarium thapsinum was isolated from $97 \%$ of the grains from field samples of infested sorghum grains in Morelos, Mexico. The influence of planting dates on the development of sorghum grain mold was determined at Tlayca, Morelos, Mexico, during the rainy seasons of 1998, 1999, and 2000. Incidence of grain mold varied annually, but disease incidence and severity were highest in 1998. Planting dates from 1 June to 13 July had the highest incidence of grain mold during the 3 years. Throughout the study, disease severity was generally low, and yield was not affected. The late planting dates in 1999 and 2000 had reduced yields due to terminal drought of the crop. Increase of disease was predicted by mean temperature, but not by mean relative humidity.
\end{abstract}

Additional keywords: grain diseases, Sorghum bicolor

Grain mold of sorghum is a worldwide disease that affects grain quantity by decreasing grain size and grain quality by reducing nutritional value. The fungi that cause this disease are capable of producing mycotoxins, which are a threat to the health of people and animals who consume these grains $(6,15)$. About 40 genera of fungi have been detected in moldy sorghum grain. The most common are: Fusarium thapsinum Klittich, Leslie, Nelson \& Marasas, F. semitectum Berk. \& Ravenel, Colletotrichum graminicola (Ces.) G.W. Wilson, Alternaria alternata (Fr.:Fr.) Keissl., Phoma sorghina (Sacc.) Boerema, Dorenbosch, \& Van Kesteren, and Curvularia lunata (Wakk.) Boedijn (10). Grain mold is a problem of early maturing sorghum in regions where flowering and grain filling occur during periods of high relative humidity and warm temperatures (28 to $37^{\circ} \mathrm{C}$ ). The disease prevails in humid tropical and subtropical areas, mainly in India, Africa, and Latin America (15). Yield

Corresponding author: R. Montes-Belmont E-mail: rbelmont@ipn.mx

Accepted for publication 12 May 2003.

Publication no. D-2003-0707-03R

(C) 2003 The American Phytopathological Society losses range from 30 to $100 \%$ depending on genotype and type of soil (10). One method of control is the use of hybrids that develop and ripen their grains after the rainy season ends. These cultivars often suffer terminal drought and consequently produce poor yields. Genetic resistance is an appealing method of control, but there are no resistant cultivars available (11).

One deterrent to the development of management practices for sorghum grain mold is the lack of epidemiological studies on optimal relative humidity and temperature required for infection by the predominant pathogenic species (14). In México, there is limited information about sorghum grain mold. Fusarium moniliforme was isolated from all parts of the plant, including the grain, in several locations in the state of Guanajuato (8). In the state of Morelos, Diaz (4) reported that sorghum panicle blight was caused by $F$. moniliforme, but he did not determine if this fungus infects grains or report its distribution and importance.

The state of Morelos in Mexico is an important sorghum producing area with a warm, subhumid climate, located less than $1,400 \mathrm{~m}$ above sea level. Annual mean precipitation is $800 \mathrm{~mm}$ (mainly in summer), and annual mean temperature is $22^{\circ} \mathrm{C}$ $\left(18^{\circ} \mathrm{C}\right.$ in the coldest months). From 1990 to 1997 , an annual average of 30,581 ha of sorghum was planted, which produced 101,527 metric tons of grain (12).

The objectives of this study were (i) to identify the fungi associated with grain mold and (ii) to explore the relationship among planting dates, disease development, and relative humidity and temperature in Morelos, Mexico.

\section{MATERIALS AND METHODS}

Fungi associated with grain mold. In 1998, diseased grains were collected from Tlayca, Yautepec, and Axochiapan in the state of Morelos. The predominant hybrids in these locations were Pioneer 8313 and Pioneer 8418. At each location, 250 diseased grains were randomly collected from each of three sorghum fields. In the laboratory, the grains were surface-sterilized for 10 min with sodium hypochlorite (5\%), rinsed twice with sterile water, plated on potato dextrose agar (PDA), and incubated under $14 \mathrm{~h}$ light $/ 10 \mathrm{~h}$ dark at $24^{\circ} \mathrm{C}$ for 5 days (13). After fungal colony development, the genus and species of each fungus was identified using the morphological characteristics of mycelia and conidia $(1,5,7,9)$. The frequency $(\%)$ of each fungus isolated was calculated based on the total of diseased grains sampled $(2,250$ grains).

Relationship between planting dates and grain mold development. Experiments were conducted in the village of Tlayca, Jonacatepec County, Morelos State, Mexico, during the rainy seasons of 1998, 1999, and 2000 to examine the relationship between planting date and development of grain mold. Sorghum had been grown on this test site for more than 15 years, but only in the last 5 years have growers observed grain mold. Other sorghum fields near the experimental plots also had experienced grain mold. Due to variations in rain among the seasons, planting dates were established as follows: 25 June and 2, 14, and 21 July in 1998; 15 and 29 June and 13 and 27 July in 1999; and 30 June, 13 and 25 July, and 3 August in 2000.

Recommended agronomic practices for the region were followed during the growing season. A complete randomized block design was used each year, with four planting dates and six replications. Sorghum hybrid Pioneer 8418 (one of the most widely grown cultivars in the area) was 
planted in plots that consisted of 8 rows each $10 \mathrm{~m}$ long. Yield and disease data were collected from $8 \mathrm{~m}$ in the middle of the two center rows (mean of 435 plants per plot). The number of plants per plot with grain mold symptoms was recorded weekly for each planting date from the beginning of grain development to harvest. These data were transformed into incidence per sampling date by calculating the percentage of diseased panicles from the total of panicles in the plot sampled area (mean of 643 panicles on main shoots and tillers each of the 3 years). At harvest, disease severity was determined for all the panicles in each plot prior to yield determination. Disease severity rating was based on the following scale: $1=$ no affected grains per panicle, $2=1$ to $10,3=$ 11 to $25,4=26$ to 50 , and $5=$ more than 50 affected grains per panicle. All data were subjected to analysis of variance and Tukey's test for mean comparison. Each year was analyzed separately.

Relationship between disease and climatic variables. During the phenological stage (grain milk stage to physiological maturity when black layer formation was 7 days old) when sorghum Pioneer hybrid 8418 is susceptible to the disease, disease incidence was recorded weekly in each plot. Weather data were recorded from July to November using a hygrothermograph (Oakton, Mod. 37250-10; Cole Parmer, Chicago, IL) that was placed at a distance of $15 \mathrm{~m}$ from the experimental area. Data obtained from the hygrothermograph was used to calculate weekly averages of the following parameters: (i) Mean temperature and relative humidity (data from 0000 to 2400 hours). (ii) Daytime temperature and relative humidity (data from 0800 to
1800 hours). (iii) Nighttime temperature and relative humidity (data from 1900 to 0700 hours). (iv) Minimum temperature and relative humidity (minimum of both weather variables for each $24 \mathrm{~h}$ ). (v) Maximum temperature and relative humidity (maximum of both weather variables for each $24 \mathrm{~h}$ ).

The incidence (\%) of grain mold was determined each week, and the percent change in disease incidence $(D I)$ from one week to the next was calculated using the equation:

$$
\frac{D I_{i}-D I_{i-1}}{D I_{i-1}}=\begin{aligned}
& \text { percent change in } \\
& \text { disease incidence }
\end{aligned}
$$

where $D I_{i}$ is the average incidence of disease (from the six replications) for each planting date for each week $(i)$.

To evaluate the impact of weather conditions on the increase of disease incidence,
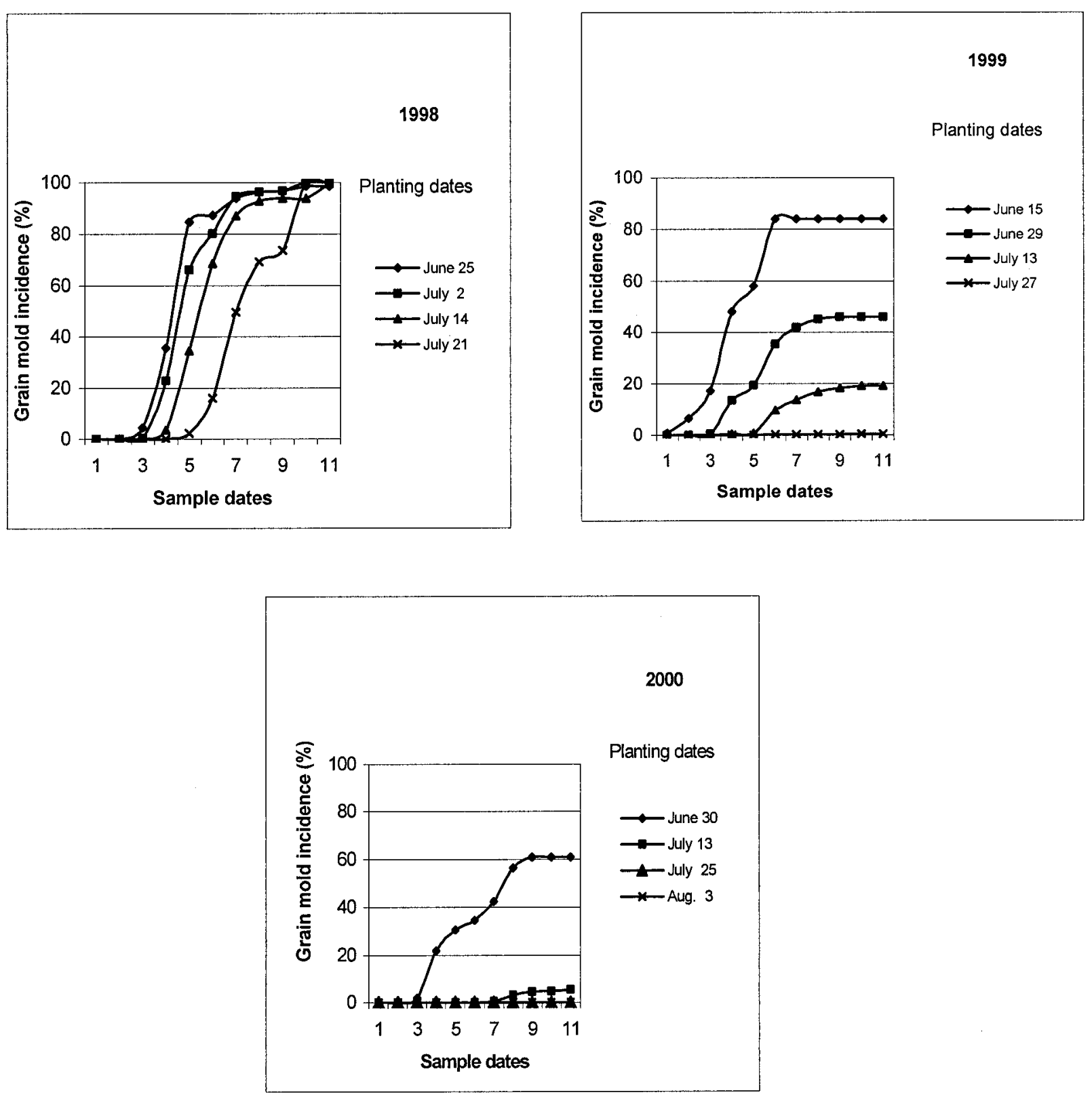

Fig. 1. Percent incidence of grain mold over four planting dates in 1998 to 2000 at Tlayca, Morelos, Mexico. 
climatic variables during the 3 years were used to develop regression models. The first model included all values of the percent change in disease incidence during the 3 years. The second model included only those values of change in disease incidence greater than $10 \%$. The weekly percent change in disease incidence was the dependent variable in these regressions. Years, planting dates, and all weather parameters mentioned previously were the independent variables. Since the years and planting dates are categorical variables, and there is variation in the percent change of disease incidence, temperature, and relative humidity within years and planting dates, years and planting dates were treated as blocks in the regression analysis. All interactions between weather data and the categorical data (planting dates and years) were also included in the regression. A stepwise selection procedure was used. When there are categorical factors, this procedure searches for the set of contrasts between variables that best explains the change in disease. These contrasts are used in the stepwise selection as single degrees of freedom.

Since the plants did not produce grain during the later planting dates, the percent change in disease incidence was zero regardless of climatic conditions. All instances in which disease incidence was zero were not included in the analysis. The Box-Cox transformation (3) was used to ensure that residuals of the regression models met the assumptions of normality and homogeneity of variances. All statistical analyses were conducted using version 3.2 of the JMP software (SAS Institute, Cary, NC).

\section{RESULTS}

Fungi associated with grain mold. Three types of symptoms were observed on sorghum seed from the collected grain samples: 1 . seeds with a powdery, whitepink appearance that were small in size, failed to mature properly, and shrank after drying; 2 . seeds with a shiny, velvety, black fluffy growth on grain surface, but not different in size from normal grains; and 3. seeds with a dull gray-black mycelium on grain surface and normal size. Fusarium species were recovered from $97 \%$ of the isolations. On PDA, the mycelium grew slowly (52 to $63 \mathrm{~mm}$ after 7 days) and produced a yellow pigment around the fungal colony. Sporodochia were not produced. Microconidia were ovoid to oval, with a single septa or aseptate, and 8 to 18 (mean 11.3) $\times 2$ to 3 (mean 2.5) $\mu \mathrm{m}$, as described for $F$. thapsinum (7). These isolates were predominately associated with sorghum seeds with a powdery, white-pink appearance and reduced size (symptom 1). The other $3 \%$ of the fungi isolated were Curvularia spp. (symptom 2) and Alternaria spp. (symptom 3). Conidia of the Alternaria isolates were formed in branched chains, had up to 8 transverse and several longitudinal septa, and were 23 to $60 \mu \mathrm{m}$ long and 10 to $17 \mu \mathrm{m}$ wide at the broadest part. Based on these characteristics, the fungus was identified as A. alternata (9). Curvularia conidia measured 18 to $32 \times 8$ to $16 \mu \mathrm{m}$, as described for $C$. lunata (5).

Relationship among planting dates, development of grain mold, and grain yield. For all of the planting dates in 1998, $100 \%$ of the panicles were infected with $F$. thapsinum by the end of the crop season, and there were no differences in disease incidence between planting dates (Fig. 1). Disease incidence in 1999 was lower than in 1998, and only the first planting date (15 June) had a disease incidence greater than $50 \%(83 \%)$ at the end of the season. For the fourth planting date (27 July), disease incidence was less than $1 \%$. Disease incidence at the end of the season was different for each planting date in 1999. In 2000, disease incidence was significantly higher at the first planting date (29 June) than at the other planting dates. Grain infection was not observed in the second and fourth planting dates (25 July and 3 August), which were not significantly different from the third planting date with $6.0 \%$ infection.

In 1998, 3 (11 to 25 grains infected per panicle) was the most frequent disease severity rating during the first three planting dates (Table 1). For the last planting date, disease severity ratings of 1 to 4 occurred at the same frequency. In 1999 and 2000, disease severity ratings 1 and 2 accounted for more than $86 \%$ of ratings.

Although disease incidence was highest in 1998, yield among planting dates was not significantly different (Table 1). In 1999 , yield was decreased by greater than $50 \%$ on the last planting date (27 July) compared with the first three planting dates (15 to 29 June and 13 July). In 2000, compared with the first planting date (30 June), yield decreased by 43 and $57 \%$ on the third (25 July) and fourth (3 August) planting dates, respectively. The reductions in yield in 1999 and 2000 occurred despite the low incidence of grain mold.

Table 2. Sources of variation that resulted in an increase in the percentage of disease incidence

\begin{tabular}{lccrr}
\hline Source of variation $^{\mathbf{z}}$ & df & Sum of squares & $\boldsymbol{F}$ & $\boldsymbol{P}$ \\
\hline Temperature & 1 & 433.0 & 5.73 & 0.0200 \\
Year (temperature) & 1 & $2,175.9$ & 28.78 & $<0.0001$ \\
$\quad(1998$ vs. 1999,2000) & 1 & & & \\
Planting dates (temperature) & & 580.5 & 7.68 & 0.0067 \\
$\quad(1$ vs. 2,3,4) & 97 & $7,333.0$ & & \\
Error & 100 & $10,470.5$ & & \\
Total & & & \\
\hline
\end{tabular}

${ }^{\mathrm{z}}$ Main effects were year, planting date, temperature, and relative humidity, and all interactions among these factors were analyzed using stepwise selection. These sources of variation are the significant contrasts selected by JMP software.

Table 1. Frequency of disease severity ratings for grain mold and sorghum grain yield among planting dates from 1998 to 2000 in Morelos, Mexico

\begin{tabular}{|c|c|c|c|c|c|c|c|}
\hline \multirow[b]{2}{*}{ Year } & \multirow[b]{2}{*}{ Planting dates } & \multicolumn{5}{|c|}{ Frequency of disease severity ratingy } & \multirow{2}{*}{$\begin{array}{c}\text { Yield } \\
\left(\text { ton ha- } \mathbf{h a}^{-1}\right)^{\mathbf{z}}\end{array}$} \\
\hline & & 1 & 2 & 3 & 4 & 5 & \\
\hline \multirow[t]{4}{*}{1998} & June 25 & $0.7 \mathrm{~b}$ & $26.8 \mathrm{a}$ & $40.0 \mathrm{a}$ & $24.0 \mathrm{a}$ & $8.5 \mathrm{a}$ & $5.77 \mathrm{a}$ \\
\hline & July 2 & $0.3 \mathrm{~b}$ & $27.7 \mathrm{a}$ & $42.8 \mathrm{a}$ & $18.2 \mathrm{a}$ & $11.0 \mathrm{a}$ & $5.64 \mathrm{a}$ \\
\hline & July 14 & $0.7 \mathrm{~b}$ & $32.9 \mathrm{a}$ & $42.9 \mathrm{a}$ & $18.0 \mathrm{a}$ & $5.5 \mathrm{a}$ & $5.29 \mathrm{a}$ \\
\hline & July 27 & $21.4 \mathrm{a}$ & $24.8 \mathrm{a}$ & $26.0 \mathrm{~b}$ & $19.7 \mathrm{a}$ & $8.1 \mathrm{a}$ & $5.29 \mathrm{a}$ \\
\hline \multirow[t]{4}{*}{1999} & June 15 & $16.0 \mathrm{~b}$ & $70.0 \mathrm{a}$ & $10.0 \mathrm{a}$ & $3.0 \mathrm{a}$ & $1.0 \mathrm{a}$ & $5.84 \mathrm{a}$ \\
\hline & June 29 & $55.0 \mathrm{a}$ & $40.3 \mathrm{a}$ & $4.1 \mathrm{~b}$ & $0.5 \mathrm{a}$ & $0.1 \mathrm{a}$ & $5.71 \mathrm{a}$ \\
\hline & July 13 & $81.5 \mathrm{a}$ & $17.3 \mathrm{~b}$ & $1.1 \mathrm{~b}$ & $0.1 \mathrm{a}$ & $0.0 \mathrm{a}$ & $5.52 \mathrm{a}$ \\
\hline & July 27 & $99.5 \mathrm{a}$ & $0.5 \mathrm{~b}$ & $0.0 \mathrm{~b}$ & $0.0 \mathrm{a}$ & $0.0 \mathrm{a}$ & $2.33 \mathrm{~b}$ \\
\hline \multirow[t]{4}{*}{2000} & June 30 & $28.5 \mathrm{a}$ & $63.0 \mathrm{a}$ & $7.0 \mathrm{a}$ & $0.5 \mathrm{a}$ & $0.0 \mathrm{a}$ & $5.63 \mathrm{a}$ \\
\hline & July 13 & $96.9 \mathrm{a}$ & $3.1 \mathrm{~b}$ & $0.0 \mathrm{~b}$ & $0.0 \mathrm{a}$ & $0.0 \mathrm{a}$ & $5.40 \mathrm{a}$ \\
\hline & July 25 & $100.0 \mathrm{a}$ & $0.0 \mathrm{~b}$ & $0.0 \mathrm{~b}$ & $0.0 \mathrm{a}$ & $0.0 \mathrm{a}$ & $2.81 \mathrm{~b}$ \\
\hline & August 3 & $100.0 \mathrm{a}$ & $0.0 \mathrm{~b}$ & $0.0 \mathrm{~b}$ & $0.0 \mathrm{a}$ & $0.0 \mathrm{a}$ & $2.42 \mathrm{~b}$ \\
\hline
\end{tabular}

${ }^{\mathrm{y}}$ Disease severity rating based on a scale of 1 to 5 , where $1=0,2=1$ to $10,3=11$ to $25,4=26$ to 50 , and $5=>50$ diseased grains per panicle.

${ }^{\mathrm{z}}$ Means in a column within each year followed by the same letter are not statistically different according to Tukey's test at $P=0.05$. Each year was analyzed separately. 
Relationship between incidence of grain mold and climatic factors. In the first regression model, which included all sampling dates with disease incidence greater than zero, disease severity was significantly influenced by mean temperature between years (1998 versus 1999 and 2000 ) and planting dates ( 1 versus 2, 3, and 4) (Table 2). A linear relationship was obtained for the following: (i) 1998 and planting date 1, (ii) 1998 and planting dates 2, 3, and 4, (iii) 1999 and 2000 and planting date 1, and (iv) 1999 and 2000 and planting dates 2, 3, and 4 (Fig. 2). The test for lack of fit was not significant, which indicated that the model was appropriate. The regression coefficient for mean temperature was 1.64.

In the second regression model, which included only data of increase of disease greater than $10 \%$, mean relative humidity was the only significant independent factor. The response of disease increase to relative humidity among years and planting dates is shown in Figure 3.

\section{DISCUSSION}

The high frequency of isolation of $F$. thapsinum from moldy grain is similar to the results obtained by Singh and Bandyopadhyay (10), who identified $F$. thapsinum as the most common component of sorghum grain mold.

In this study, disease severity was often low regardless of disease incidence. The low levels of disease severity indicate that although the frequency of panicles that are diseased can be high, the number of infected grains per panicle can remain low.

Despite differences in disease incidence, the failure to identify statistical differences in yield may be explained by the low levels of disease severity. It has been estimated that each panicle can produce between 1,500 and 2,000 grains (in a standard cultivar). In this study, only $8.5 \%$ of the panicles had more than 50 infected grains, so the impact on yield was minimal.

The drought in August and September of 1999 and 2000 had a significant effect on yield. Plants from the final planting date in 1999 and the last two planting dates in
2000 were in the process of vegetative development or had already started flowering. The leaves of the plants were desiccated and the panicles were smaller with fewer grains. Plants from the earlier planting dates were still green. Borrell et al. (2) demonstrated that the effects of terminal drought are expressed as leaf senescence and a reduction in the production of biomass.

The increase in disease incidence was predicted by mean temperature. The high-

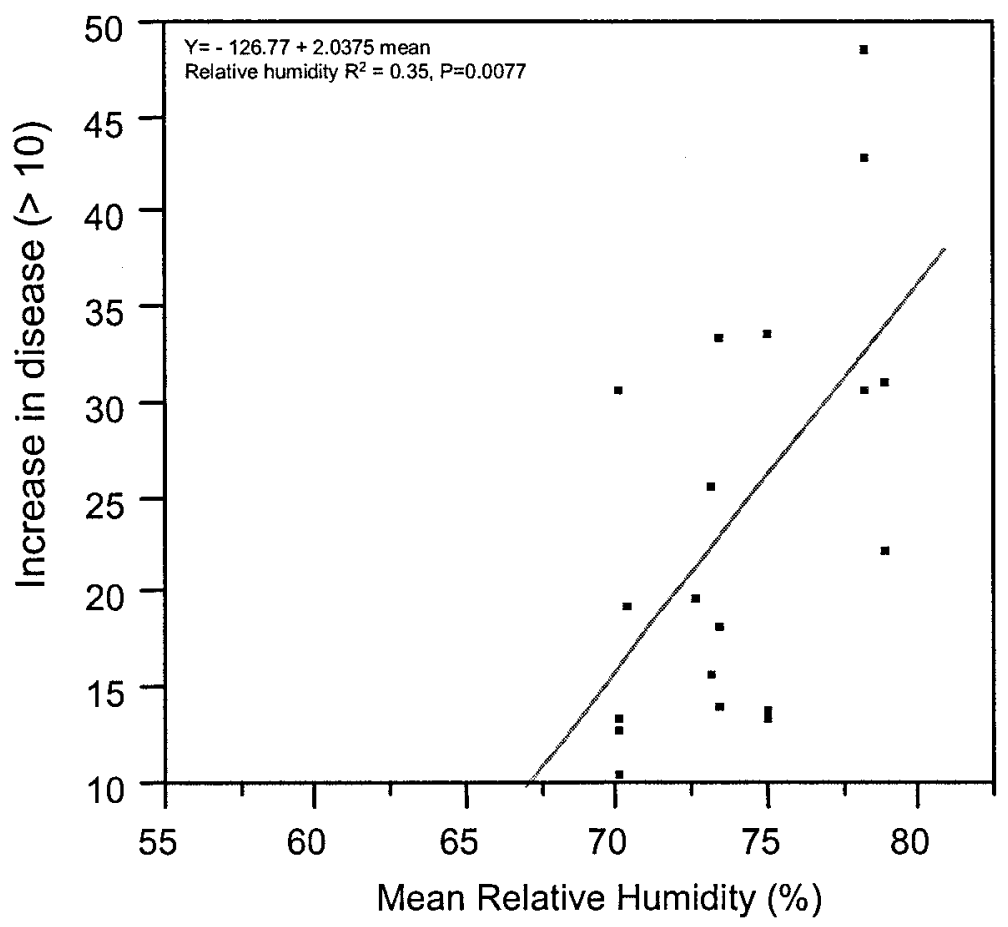

Fig. 3. Linear regression model for relationship between percent increase in grain mold greater than $10 \%$ and mean relative humidity.

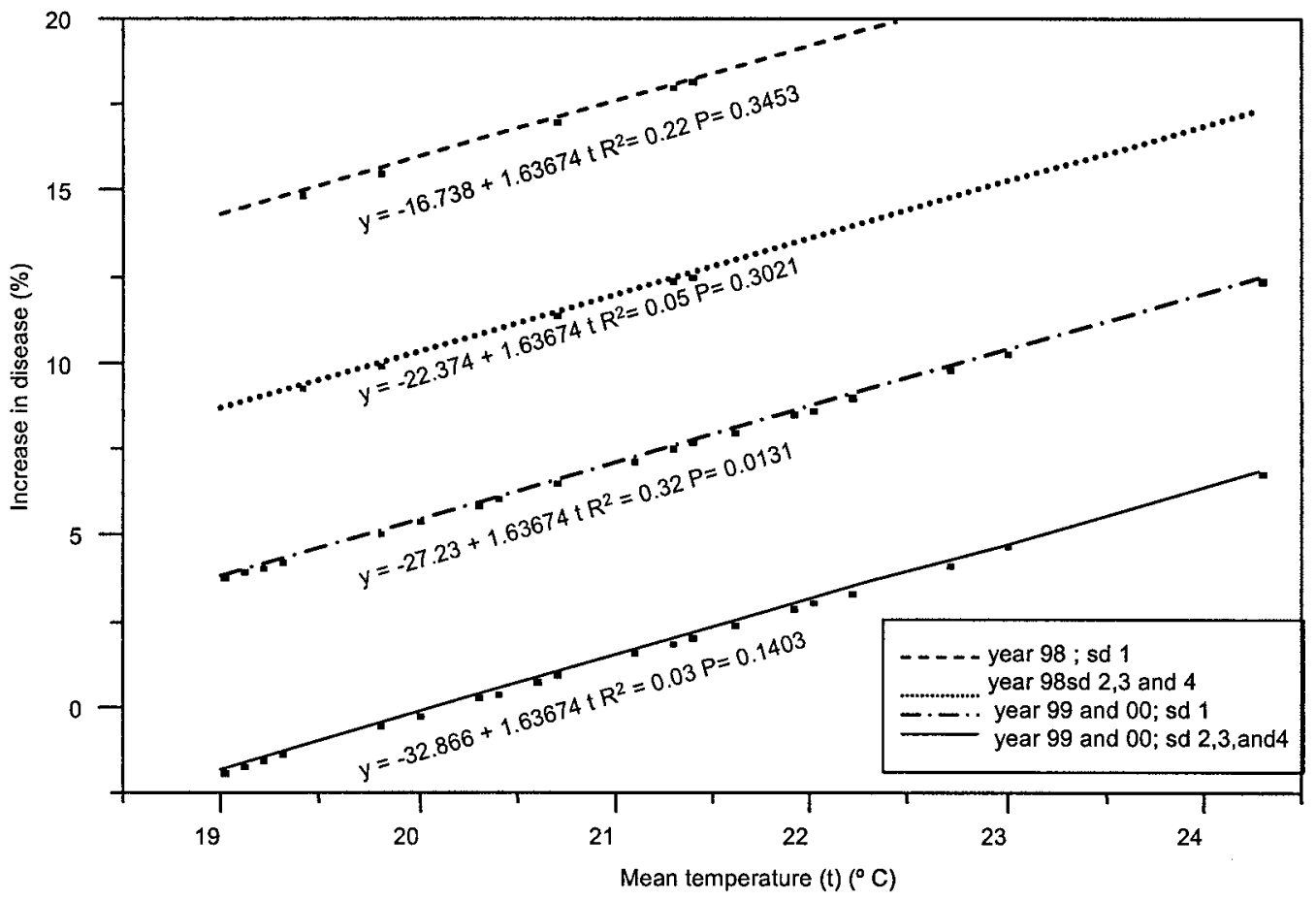

Fig. 2. Linear regression models for increase in percentage of grain mold by mean temperature among years and planting dates. 
est increase in disease incidence was recorded when weekly mean temperature fluctuated from 20 to $24^{\circ} \mathrm{C}$. When only increases in disease incidence greater than $10 \%$ were used, relative humidity was significant. Although relative humidity was significant, its predictive value was limited, as indicated by the low coefficient of determination $\left(R^{2}=0.35\right)$.

Grain mold did not reduce yields in this study, which suggests that grain mold is not a serious problem in Morelos, Mexico; however, mycotoxins produced by $F$. thapsinum could be a potential threat to consumers (persons or animals) of sorghum.

\section{LITERATURE CITED}

1. Barnett, H. L., and Hunter, B. B. 1999. Illustrated Genera of Imperfect Fungi. 4th ed. American Phytopathological Society, St. Paul, MN.

2. Borrell, A. K., Hammer, G. L., and Henzell, R. G. 2000. Does maintaining green leaf area in sorghum improve yield under drought? II. Dry matter production and yield. Crop Sci. 40:1037-1061.
3. Box, G. E. P., and Cox, D. R. 1964. An analysis of transformations. J. Roy. Stat. Soc. B26, 211-243.

4. Díaz, B. V. 1983. Enfermedades del sorgo en Morelos. Folleto Técnico No. 4 Secretaría de Agricultura y Recursos Hidráulicos. Instituto Nacional de Investigaciones Agrícolas. Campo Agríc. Exp. Zacatepec. 12-13.

5. Ellis, M. B. 1966. Dematiaceuous hyphomycetes. VII Curvularia. C.M.I. Mycol. Pap. No. 106.

6. Forbes, G. A., Bandyopadhyay, R., and Garcia, G. 1992. A review of sorghum grain mold. Pages 265-272 in: Sorghum and Millets Diseases: A Second World Review. W. A. J. de Milliano, R. A. Frederiksen, and G. D. Bengston, eds. International Crops Research Institute for the Semiarid Tropics, Patancheru, India.

7. Klittich, C. J. R., Leslie, J. F., Nelson, P. E., and Marasas, W. F. O. 1997. Fusarium thapsinum (Gibberella thapsina): A new specie in section Liseola from sorghum. Mycologia 89:643-652.

8. Narro, S. J., S. Osada K., E. Redondo J y J. Ortega S. 1992. Especies de Fusarium en diferentes etapas fenológicas y tejidos de la planta de sorgo (Sorghum bicolor (L.) Moench), en el Estado de Guanajuato. Rev. Mex. Fitopatol. 10:192-199.

9. Simmons, E. G. 1967. Typification of Alter- naria, Stemphylium and Ulocladium. Mycologia 59:67-92.

10. Singh, S. D., and Bandyopadhyay, R. 2000. Panicle and seed diseases. Grain mold. Pages 38-40 in: Compendium of Sorghum Diseases. 2nd ed. R. A. Frederiksen and G. N. Odvody, eds. American Phytopathological Society, St. Paul, MN.

11. Stenhouse, J. W., Bandyopadhyay, R., Singh, S. D., and Subramanaian, V. 1997. Breeding for grain mold resistance in sorghum. Pages 326-336 in: Proc. Int. Conf. Genet. Improve. Sorghum Pearl Millet, Lubbock, TX.

12. Vásquez, A. J. M. P., and J. A. Ávila, M 1999. El sorgo: un mercado globalizado. Como se produce y comercializa sorgo actualmente. Publicación especial No. 17. Secretaría de Agricultura, Ganadería y Desarrollo Rural. Instituto Nacional de Investigaciones Forestales, Agrícolas y Pecuarias. Campo Experimental Zacatepec. Mexico.

13. Warman, E. J., Butler, L. D., and Sutton, B. C 1995. Ensayos para la semilla de maìz y de trigo. CIMMYT, Mexico, D.F.

14. Williams, R. J., and McDonald, D. 1983. Grain molds in the tropics: Problems and importance. Annu. Rev. Phytopathol. 21:153-178.

15. Williams, R. J., and Rao, K. N. 1981. A review of sorghum grain moulds. Trop. Pest Manag. 27:200-211. 